\title{
PENINGKATAN KUALITAS PROSES DAN HASIL PEMBELAJARAN MATERI KEMAGNETAN MELALUI METODE EXPLORATION LEARNING MODEL
}

\author{
SUSI HIDAYANTI \\ SMP Negeri 1 Jember \\ e-mail: susihidayanti06@gmail.com
}

\begin{abstract}
ABSTRAK
Penelitian ini berlatar belakang pada kenyataan bahwa keberhasilan dalam pembelajaran belum maksimal, karena rendahnya kualitas proses dan hasil belajar, akibatnya belum terciptanya PAKEM (Pembelajaran Aktif Kreatif Efektif dan Menyenangkan) khususnya di kelas IX-D SMPN 1 JEMBER. Dalam pembelajaran minat, motivasi, kemandirian, antusias, aktivitas bertanya dan kerja sama dalam kelompok rendah. Kualitas proses siswa dan kualitas proses guru meningkat setelah menerapkan exploration learning model. Hal ini ditunjukkan dari hasil lembar pengamatan siswa yang mengalami peningkatan di setiap siklusnya. Terdapat peningkatan dari siklus I ke siklus II yaitu berturut-turut $51,51 \%$ dan 85,42\% yang mengindikasikan bahwa tingkat keberhasilan tercapai dengan kualifikasi sangat baik. Selain itu hasil penelitian juga menunjukkan bahwa penerapan exploration learning model dapat meningkatkan proses pembelajaran pada siswa dan guru mata pelajaran IPA khususnya di kelas IX-D. Perbaikan di setiap siklus membuat aktivitas siswa dan guru juga mengalami peningkatan. Persentase pengumpulan tugas siswa secara individu untuk siklus I dan II berturut-turut $72,88 \%$ dan $85,42 \%$, yang mana mengindikasikan bahwa penerapan exploration learning model juga dapat meningkatkan pengumpulan tugas belajar siswa secara individu. Persentase dalam ketuntasan hasil belajar sebelum dilakukan penelitian 39,39\%, siklus $145,83 \%$ dan siklus II $100 \%$ yang mengindikasikan bahwa penerapan exploration learning model dalam hal ini juga dapat meningkatkan kualitas proses pembelajaran pada guru dan siswa pada materi kemagnetan siswa kelas IX-D di SMPN 1 JEMBER.
\end{abstract}

Kata Kunci: Exploration Learning Model, Kualitas Proses Pembelajaran

\section{PENDAHULULAN}

Agar kegiatan belajar dan pembelajaran berhasil mengantarkan siswa mencapai tujuan pelajaran, maka salah satu faktor yang harus dipahami oleh guru adalah prinsip belajar. Tanpa memahami prinsip belajar ini sulit bagi guru untuk menyusun strategi pembelajaran, metode pembelajaran, dan teknik evaluasi yang sesuai dengan karakteristik kelas dan materi yang disajikan. Materi akan lebih mudah dikuasai apabila siswa terlibat secara emosional dalam kegiatan belajar pembelajaran. Siswa akan terlibat secara emosi dalam kegiatan pembelajaran jika pelajaran bermakna baginya (Abdorrakhman G, 2008:4).

Suksesnya kegiatan pembelajaran tidak bisa lepas dari peran guru, komponen guru merupakan salah satu komponen penting yang mempengaruhi keberhasilan belajar siswa. Hal ini karena guru merupakan orang pertama yang bertanggungjawab 
terhadap berhasil tidaknya materi pelajaran yang disampaikan, tanpa adanya peran seorang guru, maka proses pembelajaran tidak akan berhasil. Bagaimanapun pandainya siswa, jika tidak ada bimbingan dan bantuan dari guru, maka kemampuannya tidak akan terasah dengan baik. Walaupun secara kontekstual, dan secara konsep pembelajaran yang dikembangkan dalam pembelajaran telah disosialisasikan oleh pemerintah melalui kementerian terkait kepada para guru, namun tak dapat dipungkiri, masih terdapat guru yang belum mampu mengimplementasikan dalam praktik nyata di sekolah. Hal ini ditambah dengan KKM (Kriteria Ketuntasan Minimal) dari setiap mata pelajaran yang semakin meningkat, sementara itu SDM siswa sebagian besar masih belum memuaskan. Akibat dari permasalahan ini tentunya berdampak negatif terhadap kualitas pembelajaran.

Berdasarkan hasil studi awal yang peneliti lakukan sebagai observasi pada 3 siswa kelas IX-D SMPN 1 Jember yang dilaksanakan pada tanggal 23 Januari 2020 pada materi Kemagnetan, yang mana guru menerapkan metode ceramah, tanya jawab dan tugas individu, diidentifikasi kualitas proses (minat, motivasi, apresiasi, antusias, disiplin, perhatian dan tanggung jawab) dan hasil pembelajaran (nilai tugas individu siswa) belum maksimal dan belum mampu mencapai tujuan sehingga belum tercipta PAKEM dari sisi guru dan siswa. Kualitas proses pembelajaran berdasarkan hasil observasi guru/peneliti tentang (minat, motivasi, kemandirian, antusias, kerja sama kelompok, bertanya pada guru, dan menjawab pertanyaan guru) pada studi awal dapat disampaikan Nilai rata-rata kualitas proses pembelajaran materi Kemagnetan pada siswa kelas IX-D SMPN 1 Jember studi awal = 2,14 kategori rendah. Nilai yang dicapai tersebut belum mampu mencapai indikator keberhasilan sehingga perlu ada perbaikan dan peningkatan kualitas proses pembelajaran. Rekapitulasi Nilai Tugas Individu Studi Awal, Nilai rata-rata tugas individu pada materi Kemagnetan pada siswa kelas IX-D SMPN 1 Jember studi awal $=65,82$ kategori rendah. Sedangkan nilai persentase ketuntasan masih 39,39\% kategori amat kurang. Nilai yang dicapai tersebut belum mampu mencapai indikator keberhasilan sehingga perlu ada perbaikan dan peningkatan kualitas proses pembelajaran. Permasalahan yang peneliti temui selama kegiatan observasi dan yang telah dijelaskan di atas, maka peneliti akan melakukan tindakan untuk mengatasi permasalahan tersebut secara cepat, yaitu dengan bentuk penelitian sederhana yang dapat dilakukan guru sambil melaksanakan tugas mengajarnya adalah penelitian tindakan kelas (classroom action research). Penelitian tindakan kelas merupakan penyelidikan secara sistematis dengan tujuan menginformasikan praktik pembelajaran dalam situasi tertentu. Penelitian tindakan kelas juga merupakan suatu cara bagi guru untuk menemukan apa yang terbaik di dalam situasi kelas mereka sendiri sehingga keputusan tentang proses pembelajaran dapat diambil sebaik-baiknya (Mohammad Asrori, 2007:3). Oleh karena itu untuk mengimplementasikan penelitian tindakan kelas dalam peningkatan dan pengentasan masalah tersebut dapat diaplikasikan dengan penerapan exploration learning model. Model eksplorasi adalah suatu cara mengajar, di mana siswa melakukan suatu menjelajahi percobaan tentang sesuatu hal, mengamati prosesnya serta menuliskan hasil percobaannya, kemudian hasil pengamatan itu disampaikan ke kelas dan dievaluasi oleh guru. Diharapkan dengan diterapkannya exploration learning model ini 
nilai kualitas proses dan hasil pembelajaran materi Kemagnetan menjadi semakin meningkat.

Model eksplorasi adalah suatu cara mengajar, di mana siswa melakukan eksplorasi suatu percobaan tentang sesuatu hal, mengamati prosesnya serta menuliskan hasil percobaannya, kemudian hasil pengamatan itu disampaikan ke kelas dan dievaluasi oleh guru. Kelebihan model eksplorasi sebagai berikut: (a) Model ini dapat membuat anak didik lebih percaya atas kebenaran atau kesimpulan berdasarkan percobaannya sendiri daripada hanya menerima kata guru atau buku. (b) Anak didik dapat mengembangkan sikap untuk mengadakan studi eksplorasi (menjelajahi) tentang ilmu dan teknologi. (c) Dengan model ini akan terbina manusia yang dapat membawa terobosan-terobosan baru dengan penemuan sebagai hasil percobaan yang diharapkan dapat bermanfaat orang lain.

Sedangkan kekurangan model eksplorasi sebagai berikut: (a) Tidak cukupnya alat-alat mengakibatkan tidak setiap anak didik berkesempatan mengadakan eksperimen. (b) Jika eksplorasi memerlukan jangka waktu yang lama, anak didik harus menanti untuk melanjutkan pelajaran. (c) Model ini lebih sesuai untuk menyajikan bidang-bidang ilmu dan teknologi. Penggunaan teknik ini mempunyai tujuan agar siswa mampu mencari dan menemukan sendiri berbagai jawaban atau persoalanpersoalan yang dihadapinya dengan mengadakan percobaan sendiri. Juga siswa dapat terlatih dalam cara berpikir yang ilmiah. Dengan eksplorasi siswa menemukan bukti kebenaran dari teori sesuatu yang sedang dipelajarinya. Agar penggunaan model eksplorasi itu efisien dan efektif, maka perlu diperhatikan hal-hal sebagai berikut: (a) Dalam eksplorasi setiap siswa harus mengadakan percobaan, maka jumlah alat dan bahan atau materi percobaan harus cukup bagi tiap siswa. (b) Agar eksplorasi itu tidak gagal dan siswa menemukan bukti yang meyakinkan, atau mungkin hasilnya tidak membahayakan, maka kondisi alat dan mutu bahan percobaan yang digunakan harus baik dan bersih. (c) Dalam eksplorasi siswa perlu teliti dan konsentrasi dalam mengamati proses percobaan, maka perlu adanya waktu yang cukup lama, sehingga mereka menemukan pembuktian kebenaran dari teori yang dipelajari itu. (d) Siswa dalam eksplorasi adalah sedang belajar dan berlatih, maka perlu diberi petunjuk yang jelas, sebab mereka selain memperoleh pengetahuan, pengalaman serta keterampilan, juga kematangan jiwa dan sikap perlu diperhitungkan oleh guru dalam memilih obyek eksplorasi itu. (e) Tidak semua masalah bisa dieksplorasikan, seperti masalah mengenai kejiwaan, beberapa segi kehidupan sosial dan keyakinan manusia.

Kemungkinan lain karena sangat terbatasnya suatu alat, sehingga masalah itu tidak bisa diadakan percobaan karena alatnya belum ada. Dalam model eksplorasi, guru dapat mengembangkan keterlibatan fisik dan mental, serta emosional siswa. Siswa mendapat kesempatan untuk melatih ketrampilan proses agar memperoleh hasil belajar yang maksimal. Pengalaman yang dialami secara langsung dapat tertanam dalam ingatannya. Keterlibatan fisik dan mental serta emosional siswa diharapkan dapat diperkenalkan pada suatu cara atau kondisi pembelajaran yang dapat menumbuhkan rasa percaya diri dan juga perilaku yang inovatif dan kreatif. Siswa belajar secara aktif dengan mengikuti tahap-tahap pembelajarannya. Dengan demikian, siswa akan menemukan sendiri konsep sesuai dengan hasil yang diperoleh selama pembelajaran (Rusman, 2012:47). 
Sesuai dengan latar belakang masalah, maka masalah PTK (Penelitian Tindakan Kelas) ini dapat dirumuskan sebagai berikut: "Apakah peningkatan kualitas proses dan hasil pembelajaran materi kemagnetan dapat dilakukan melalui exploration learning model pada siswa kelas IX-D SMPN 1 Jember Tahun pelajaran 2019/2020?”. Adapun tujuan penelitian ini adalah "Guru IPA dapat meningkatkan Kualitas Proses dan Hasil Pembelajaran Materi Kemagnetan dapat dilakukan Melalui exploration learning model pada Siswa Kelas IX-D SMPN 1 Jember Tahun Pelajaran 2019/2020".

\section{METODE PENELITIAN}

Metode penelitian ini adalah penelitian tindakan kelas (PTK). Penelitian ini menggunakan 2 siklus yang setiap siklus terdiri dari satu kali pertemuan. Tahapan pada setiap siklus yaitu tahap perencanaan, pelaksanaan tindakan, pengamatan dan refleksi, dari tanggal 23 Januari 2020 sampai dengan 23 Februari 2020. Dengan subjek penelitian ini adalah siswa kelas IX-D SMPN 1 Jember dengan jumlah 34 siswa.

Alat pengumpulan data berupa tes, lembar observasi kualitas proses siswa dalam pembelajaran, lembar observasi aktivitas guru dalam pembelajaran. Analisis data menggunakan teknik deskriptif mean (rata-rata hitung), persentase dan katagori pada kondisi awal dan setelah diadakan penelitian di siklus 1 dan 2. Indikator keberhasilan Tindakan ini adalah jika pembelajaran pada materi kemagnetan rata-rata kelas mengalami peningkatan, persentase ketuntasan hasil belajar siswa materi kemagnetan juga meningkat, kualitas proses belajar siswa dan kualitas guru dalam pembelajaran terjadi peningkatan pada keadaan awal, siklus 1 dan siklus 2 .

\section{HASIL DAN PEMBAHASAN}

\section{Hasil Penelitian}

\section{A. Deskripsi Kondisi Awal}

Tabel 1. Kualitas Proses Pembelajaran Studi Awal

\begin{tabular}{|c|c|c|c|}
\hline No. & Aspek & Nilai & Kategori \\
\hline 1 & Minat & 2 & Kurang \\
\hline 2 & Motivasi & 2 & Kurang \\
\hline 3 & Kemandirian & 3 & Cukup \\
\hline 4 & Antusias & 2 & Rendah \\
\hline 5 & Kerja sama kelompok & 2 & Rendah \\
\hline 6 & Bertanya kepada guru & 2 & Rendah \\
\hline 7 & $\begin{array}{l}\text { Menjawab pertanyaan } \\
\text { guru }\end{array}$ & 2 & Rendah \\
\hline & Jumlah $\left(\sum_{n}\right)$ & 15 & \\
\hline & Rata-rata $(x)$ & 2,14 & Rendah \\
\hline & Indikator keberhasilan & $\bar{x} \geq 3,5$ & Baik \\
\hline & Analisis & \multicolumn{2}{|c|}{$\begin{array}{l}\text { Nilai rata-rata kualitas proses pembelajaran materi } \\
\text { Kemagnetan pada siswa kelas IX-D SMPN } 1 \text { Jember } \\
\text { studi awal = 2,14 kategori rendah. }\end{array}$} \\
\hline
\end{tabular}




\begin{tabular}{|r|l|}
\hline Refleksi & $\begin{array}{l}\text { Nilai yang dicapai tersebut belum mampu mencapai } \\
\text { indikator keberhasilan sehingga perlu ada perbaikan } \\
\text { dan peningkatan kualitas proses pembelajaran. }\end{array}$ \\
\hline Tindak lanjut & $\begin{array}{l}\text { Guru mapel melaksanakan tindakan kelas dengan } \\
\text { menerapkan exploration learning model. }\end{array}$ \\
\hline Catatan & $\begin{array}{l}\text { Tidak ada perubahan situasi kelas, tempat duduk siswa } \\
\text { tidak diubah dan pembelajaran belum melibatkan } \\
\text { teman sejawat/kolaborator. }\end{array}$ \\
\hline
\end{tabular}

Sumber Data: Hasil Observasi Peneliti Studi Awal yang diolah.

Keterangan: Hasil kualitas proses pembelajaran dari sisi guru belum diobservasi, observasi akan dilakukan pada siklus 1 dan siklus selanjutnya dengan melibatkan teman sejawat/kolaborator.

Sementara itu hasil tugas individu diperoleh data di bawah ini :

Tabel 2. Rekapitulasi Nilai Tugas Individu Studi Awal

\begin{tabular}{|c|c|c|}
\hline Aspek & Nilai & Kategori \\
\hline $\mathrm{N}$ & 34 & \\
\hline Jumlah $\left(\sum_{\mathrm{n}}\right)$ & 2172 & \\
\hline Rata-rata & 65,82 & Rendah \\
\hline Indikator keberhasilan & $\bar{x} \geq 75$ & Baik \\
\hline Siswa tuntas & 13 & \\
\hline Persentase & $39,39 \%$ & Amat Rendah \\
\hline Analisis & \multicolumn{2}{|c|}{$\begin{array}{l}\text { Nilai rata-rata tugas individu pada materi Kemagnetan } \\
\text { pada siswa kelas IX-D SMPN } 1 \text { Jember studi awal = } \\
65,82 \text { kategori rendah. Sedangkan nilai persentase } \\
\text { ketuntasan masih 39,39\% kategori amat kurang }\end{array}$} \\
\hline Refleksi & \multicolumn{2}{|c|}{$\begin{array}{l}\text { Nilai yang dicapai tersebut belum mampu mencapai } \\
\text { indikator keberhasilan sehingga perlu ada perbaikan dan } \\
\text { peningkatan kualitas proses pembelajaran. }\end{array}$} \\
\hline Tindak lanjut & \multicolumn{2}{|c|}{$\begin{array}{l}\text { Guru mapel melaksanakan tindakan kelas dengan } \\
\text { menerapkan metode exploration learning model. }\end{array}$} \\
\hline Catatan & \multicolumn{2}{|c|}{$\begin{array}{l}\text { Tugas individu menggunakan LKS, hasil tugas } \\
\text { dikumpulkan setelah selesai mengerjakan. }\end{array}$} \\
\hline
\end{tabular}

Sumber Data: Hasil Observasi Penelitian Studi Awal yang diolah.

Keterangan: $\mathrm{N}=34$ Siswa

\section{B. Deskripsi Kondisi Siklus 1}

\section{1) Kualitas Proses Pembelajaran}

Aspek kualitas proses pembelajaran yang dinilai meliputi minat, motivasi, kemandirian, antusias, kerja sama kelompok, bertanya kepada guru dan menjawab pertanyaan guru. Pedoman analisis untuk aspek kualitas proses pembelajaran jika nilai frekuensi maksimal $=5$, dan frekuensi minimal $=1$, maka rentangnya $=5-1=4$. Jika besar interval kelas ditetapkan $=5$ maka dengan menggunakan rentang jumlah kelasnya $=4 / 5=0.8$. 
Setelah ditetapkan besar interval kelas, dan diketahui jumlah kelasnya selanjutnya dapat dibuatkan pedoman analisis kualitas proses pembelajaran.

Tabel 3. Pedoman Analisis Kualitas Proses Pembelajaran

\begin{tabular}{|c|c|c|c|c|}
\hline No. & Interval Nilai & Bobot Nilai & Kategori & Keterangan tindakan \\
\hline 1 & $4.3-5.0$ & 5 & Amat tinggi & Amat berhasil \\
\hline 2 & $3.5-4.2$ & 4 & Tinggi & Berhasil \\
\hline 3 & $2.7-3.4$ & 3 & Cukup & Cukup berhasil \\
\hline 4 & $1.9-2.6$ & 2 & Rendah & Kurang berhasil \\
\hline 5 & $1.0-1.8$ & 1 & Amat rendah & Amat kurang berhasil \\
\hline
\end{tabular}

Sumber data: Hasil Olahan Peneliti dan Kolaborator.

Indikator kinerja kualitas proses pembelajaran ditetapkan minimal $=3.5$ kategori tinggi. Kualitas proses pembelajaran berdasarkan hasil observasi kolaborator melalui lembar observasi kualitas proses pembelajaran dapat dikemukakan berikut:

Tabel 4. Kualitas Proses Pembelajaran Siklus 1

\begin{tabular}{|c|c|c|c|}
\hline No. & Aspek & Nilai & Kategori \\
\hline 1 & Minat & 3 & Cukup \\
\hline 2 & Motivasi & 3 & Cukup \\
\hline 3 & Kemandirian & 3 & Cukup \\
\hline 4 & Antusias & 3 & Cukup \\
\hline 5 & Kerja sama kelompok & 3 & Cukup \\
\hline 6 & Bertanya kepada guru & 2 & Rendah \\
\hline 7 & Menjawab pertanyaan & 2 & Rendah \\
\hline & Jumlah $\left(\sum_{\mathrm{n}}\right)$ & 19 & \\
\hline & Rata-rata $(x)$ & $19 / 7=2,71$ & Cukup \\
\hline & Indikator keberhasilan & $\bar{x} \geq 3,5$ & Baik \\
\hline & Analisis & \multicolumn{2}{|c|}{$\begin{array}{l}\text { Nilai rata-rata kualitas proses pembelajaran materi } \\
\text { Kemagnetan pada siswa kelas IX-D SMPN } 1 \text { Jember } \\
\text { siklus } 1=2,71 \text { kategori cukup. }\end{array}$} \\
\hline & Refleksi & \multicolumn{2}{|c|}{$\begin{array}{l}\text { Nilai yang dicapai tersebut belum mampu mencapai } \\
\text { indikator keberhasilan sehingga perlu ada perbaikan } \\
\text { dan peningkatan kualitas proses pembelajaran. }\end{array}$} \\
\hline & Tindak lanjut & \multicolumn{2}{|c|}{$\begin{array}{l}\text { Guru mapel melaksanakan tindakan kelas dengan } \\
\text { menerapkan exploration learning model. }\end{array}$} \\
\hline & Catatan & \multicolumn{2}{|c|}{$\begin{array}{l}\text { Tidak ada perubahan situasi kelas, tempat duduk } \\
\text { siswa tidak diubah dan pembelajaran, penelitian } \\
\text { melibatkan teman sejawat/kolaborator. }\end{array}$} \\
\hline
\end{tabular}

Sumber data: hasil observasi kolaborator yang dioleh peneliti. 


\section{2) Nilai Tugas Individu}

Untuk mempermudah kerja analisis nilai tugas individu, maka terlebih dahulu dibuatkan pedoman analisis nilai rata-rata tugas individu dan analisis persentase ketuntasan hasil belajar berikut ini:

Tabel 5. Pedoman Analisis Nilai Tugas Individu

\begin{tabular}{|c|c|c|c|}
\hline No. & Interval & Kategori & Keterangan tindakan \\
\hline 1 & $91-100$ & Amat baik & Amat berhasil \\
\hline 2 & $75-90$ & Baik & Berhasil \\
\hline 3 & $60-74$ & Cukup & Cukup berhasil \\
\hline 4 & $40-59$ & Kurang & Kurang berhasil \\
\hline 5 & $<40$ & Amat kurang & Amat kurang berhasil \\
\hline
\end{tabular}

Sumber Data: Hasil Olahan Peneliti dan Kolaborator.

Sementara itu pedoman analisis persentase ketuntasan hasil belajar dapat dilihat pada tabel berikut.

Tabel 6. Pedoman Analisis Persentase Ketuntasan Hasil Belajar

\begin{tabular}{|c|c|c|c|}
\hline No. & Interval & Kategori & Keterangan tindakan \\
\hline 1 & $91-100 \%$ & Amat baik & Amat berhasil \\
\hline 2 & $75-90 \%$ & Baik & Berhasil \\
\hline 3 & $60-74 \%$ & Cukup & Cukup berhasil \\
\hline 4 & $40-59 \%$ & Kurang & Kurang berhasil \\
\hline 5 & $<40 \%$ & Amat kurang & Amat kurang berhasil \\
\hline
\end{tabular}

Sumber Data: Hasil Olahan Peneliti dan Kolaborator

Indikator kinerja untuk nilai rata-rata kelas minimal $=75$ kategori baik, dan indikator kinerja untuk persentase ketuntasan hasil belajar minimal $=75 \%$ kategori baik. Berdasarkan hasil tugas belajar siswa kepada 34 siswa kelas IX-D SMPN 1 Jember dalam mengerjakan soal-soal tentang materi Kemagnetan dapat diperoleh rekapitulasi data berikut:

Tabel 7. Rekapitulasi Nilai Tugas Individu Siklus 1

\begin{tabular}{|r|c|c|}
\hline \multicolumn{1}{|c|}{ Aspek } & Nilai & Kategori \\
\hline $\mathrm{N}$ & 34 & Cukup \\
\hline Jumlah $\left(\sum_{\mathrm{n}}\right)$ & 2405 & Baik \\
\hline Rata-rata & 72,88 & Kurang \\
\hline Indikator keberhasilan & $\bar{x} \geq 75$ & 17 siswa \\
\hline Siswa tuntas & $51,51 \%$ & $\begin{array}{l}\text { Nersentase } \\
\text { Analisis }\end{array}$ \\
& $\begin{array}{l}\text { Nilai rata-rata tugas individu pada materi Kemagnetan } \\
\text { kada siswa kelas IX-D SMPN 1 Jember siklus 1= 72,88 } \\
\text { kasih 51,51\% kategori amat kurang }\end{array}$ \\
\hline
\end{tabular}




\begin{tabular}{|r|l|}
\hline Refleksi & $\begin{array}{l}\text { Nilai yang dicapai tersebut belum mampu mencapai } \\
\text { indikator keberhasilan sehingga perlu ada perbaikan dan } \\
\text { peningkatan kualitas proses pembelajaran. }\end{array}$ \\
\hline Tindak lanjut & $\begin{array}{l}\text { Guru mapel melaksanakan tindakan kelas dengan } \\
\text { menerapkan metode exploration learning model. }\end{array}$ \\
\hline Catatan & $\begin{array}{l}\text { Tugas individu menggunakan LKS, hasil tugas } \\
\text { dikumpulkan setelah selesai mengerjakan. }\end{array}$ \\
\hline
\end{tabular}

Sumber Data: Hasil Observasi Peneliti Siklus 1 yang Diolah.

Keterangan: $\mathrm{N}=34$ Siswa

\section{3) Kualitas Guru dalam Pembelajaran}

Ada tiga aspek yang diobservasi berkaitan dengan kualitas guru dalam pembelajaran, yaitu: 1) Kesesuaian RPP dengan pelaksanaan, a) pra pembelajaran, b) kegiatan inti, dan c) penutup, 2) Upaya pemberian motivasi kepada siswa, dan 3) Pengelolaan kelas. Pedoman analisisnya berdasarkan perhitungan berikut: Jika nilai maksimal $=5$, dan nilai minimal $=1$, maka rentangnya $=5-1=4$. Jika besar interval kelas ditetapkan $=5$ maka dengan menggunakan rentang jumlah kelasnya $=4 / 5=0.8$. Setelah ditetapkan besar interval kelas, dan diketahui jumlah kelasnya selanjutnya dapat dibuatkan pedoman analisis kualitas guru dalam pembelajaran sebagai berikut.

Tabel 8. Pedoman Analisis Kualitas Guru dalam Pembelajaran

\begin{tabular}{|c|c|c|c|c|}
\hline No. & Interval Nilai & Bobot Nilai & Kategori & Keterangan Tindakan \\
\hline 1 & $4.3-5.0$ & 5 & Amat tinggi & Amat berhasil \\
\hline 2 & $3.5-4.2$ & 4 & Tinggi & Berhasil \\
\hline 3 & $2.7-3.4$ & 3 & Cukup & Cukup berhasil \\
\hline 4 & $1.9-2.6$ & 2 & Rendah & Kurang berhasil \\
\hline 5 & $1.0-1.8$ & 1 & Sangat rendah & Sangat kurang berhasil \\
\hline
\end{tabular}

Keterangan: Hasil Olahan Peneliti dan Kolaborator

Indikator kinerja kualitas guru dalam kegiatan pembelajaran ditetapkan minimal $=3.5$ kategori tinggi. Berdasarkan hasil observasi, kualitas guru dalam pembelajaran dapat dilihat pada tabel berikut:

Tabel 9. Kualitas Guru dalam Pembelajaran Siklus 1

\begin{tabular}{|c|l|c|c|c|}
\hline No. & \multicolumn{1}{|c|}{ Aspek } & Nilai & Kategori & $\begin{array}{c}\text { Keterangan } \\
\text { Tindakan }\end{array}$ \\
\hline A & Kesesuaian RPP dengan pelaksanaan & & & \\
\hline 1 & Pembelajaran & & & \\
\hline & a. Pengecekan kesiapan kelas & 4 & Tinggi & Berhasil \\
\hline & b. Apersepsi & 4 & Tinggi & Berhasil \\
\hline 2 & Kegiatan Inti & & & \\
\hline & a. Penguasaan materi & 4 & Tinggi & Berhasil \\
\hline & b. Strategi pembelajaran & 3 & Cukup & $\begin{array}{c}\text { Cukup } \\
\text { Berhasil }\end{array}$ \\
\hline & c. Penggunaan bahasa & 4 & Tinggi & Berhasil \\
\hline
\end{tabular}




\begin{tabular}{|c|l|c|c|c|}
\hline 3 & Penutup & & & \\
\hline & a. Refleksi/rangkuman & 4 & Tinggi & Berhasil \\
\hline & b. Tindak lanjut & 3 & Cukup & $\begin{array}{c}\text { Cukup } \\
\text { Berhasil }\end{array}$ \\
\hline & Jumlah & 26 & & \\
\hline & Rata-rata & $\begin{array}{c}-26 / 7= \\
3.71\end{array}$ & Cukup & $\begin{array}{c}\text { Cukup } \\
\text { Berhasil }\end{array}$ \\
\hline & & & & \\
\hline B & Pemberian Motivasi kepada Siswa & 3 & Cukup & $\begin{array}{c}\text { Cukup } \\
\text { Berhasil }\end{array}$ \\
\hline C & Pengelolaan Kelas & 3 & Cukup & $\begin{array}{c}\text { Cukup } \\
\text { Berhasil }\end{array}$ \\
\hline & Jumlah & 6 & & Cukup \\
\hline & Rata-rata & $=6 / 2=$ & Cukup & $\begin{array}{c}\text { Berhasil } \\
\text { Cukup } \\
\text { Berhasil }\end{array}$ \\
\hline & Rata-rata total & $=3.71+3=6$ & Cukup & \\
& & $\begin{array}{c}.71 / 2= \\
3.36\end{array}$ & & \\
\hline
\end{tabular}

Keterangan: Hasil Observasi Kolaborator yang diolah

Berdasar tabel di atas selanjutnya dapat dianalisis bahwa kualitas guru dalam pembelajaran siklus 1 memiliki nilai rata-rata total $=3.36$ kategori cukup. Jika dikonsultasikan dengan indikator kinerja kualitas guru dalam pembelajaran minimal = 3.5, maka nilai tersebut kurang 0.14 nilai.

\section{Deskripsi Keadaan Siklus 2}

\section{1) Kualitas proses siswa dalam pembelajaran}

Aspek kualitas proses siswa dalam pembelajaran yang diobservasi dan Indikator kinerja kualitas proses siswa dalam pembelajaran siklus 2 adalah sama dengan pada siklus 1 berdasarkan hasil observasi kolaborator melalui lembar observasi kualitas proses siswa dalam pembelajaran dapat dikemukakan sebagai berikut:

Tabel 10. Kualitas Proses Siswa dalam Pembelajaran Siklus 2

\begin{tabular}{|c|l|c|c|}
\hline No. & \multicolumn{1}{|c|}{ Aspek } & Nilai & Kategori \\
\hline 1 & Minat & 5 & Amat tinggi \\
\hline 2 & Motivasi & 4 & Tinggi \\
\hline 3 & Kemandirian & 4 & Tinggi \\
\hline 4 & Antusias & 4 & Tinggi \\
\hline 5 & Kerja sama kelompok & 4 & Tinggi \\
\hline 6 & Bertanya kepada guru & 3 & Tinggi \\
\hline 7 & Menjawab pertanyaan guru & Cukup \\
\hline \multicolumn{2}{r|}{ Jumlah $\left(\sum_{n}\right)$} & 28 & Tinggi \\
\hline \multicolumn{2}{r|}{ Indikator keberhasilan $(\bar{x})$} & 4,00 & Baik \\
\hline
\end{tabular}




\begin{tabular}{|c|c|}
\hline Analisis & $\begin{array}{l}\text { Nilai rata-rata kualitas proses pembelajaran } \\
\text { materi Kemagnetan pada siswa kelas IX-D } \\
\text { SMPN } 1 \text { Jember siklus } 2=4,00 \text { kategori } \\
\text { tinggi. }\end{array}$ \\
\hline Refleksi & $\begin{array}{l}\text { Nilai yang dicapai tersebut sudah mampu } \\
\text { mencapai indikator keberhasilan sehingga } \\
\text { tidak perlu ada perbaikan dan peningkatan } \\
\text { kualitas proses pembelajaran. }\end{array}$ \\
\hline Tindak lanjut & - \\
\hline Catatan & - \\
\hline
\end{tabular}

Sumber Data: Hasil Observasi Kolaborator.

\section{2) Nilai Tugas Individu}

Indikator kinerja untuk nilai rata-rata tugas individu pada siklus 2 ini sama dengan indikator kinerja pada siklus 1 . Indikator kinerja untuk persentase ketuntasan hasil tugas individu pada siklus 2 ini sama dengan indikator kinerja pada siklus 1 . Berdasarkan hasil tugas individu kepada 34 siswa kelas IX-D SMPN 1 Jember dalam mengerjakan soal-soal tentang materi Kemagnetan dapat diperoleh rekapitulasi data berikut:

Tabel 11. Rekapitulasi Nilai Tugas Individu Siklus 2

\begin{tabular}{|r|c|c|}
\hline \multicolumn{1}{|c|}{ Aspek } & Nilai & Kategori \\
\hline $\mathrm{N}$ & 34 & Baik \\
\hline Jumlah $\left(\sum_{\mathrm{n}}\right)$ & 2813 & Baik \\
\hline Rata-rata & 85,42 & \multicolumn{1}{c|}{ Amat tinggi } \\
\hline Indikator keberhasilan & $\bar{x} \geq 75$ & \multicolumn{1}{|c|}{} \\
\hline Siswa tuntas & 34 & $\begin{array}{l}\text { Pentase } \\
\text { Persentase }\end{array}$ \\
\hline Analisis & $\begin{array}{l}\text { Nilai rata-rata tugas individu pada materi Kemagnetan pada } \\
\text { siswa kelas IX-D SMPN 1 Jember siklus 2 = 85,42 kategori } \\
\text { kategori amat tinggi }\end{array}$ \\
\hline Refleksi & $\begin{array}{l}\text { Nilai yang dicapai tersebut sudah mampu mencapai indikator } \\
\text { keberhasilan sehingga tidak perlu ada perbaikan dan } \\
\text { peningkatan kualitas proses pembelajaran. }\end{array}$ \\
\hline Tindak lanjut & - \\
\hline Catatan & - \\
\hline
\end{tabular}

Sumber Data: Hasil Observasi Peneliti siklus 2 yang diolah.

Keterangan: $\mathrm{N}=34$ Siswa

\section{3) Kualitas guru dalam Pembelajaran}

Aspek kualitas guru dalam pembelajaran dan Indikator kinerja kualitas guru dalam pembelajaran siklus 2 sama dengan pada siklus 1 .

Berdasarkan hasil observasi, kualitas guru dalam kegiatan pembelajaran dapat dilihat pada tabel berikut: 
Tabel 12. Kualitas guru dalam Pembelajaran Siklus 2

\begin{tabular}{|c|c|c|c|c|}
\hline No. & Aspek & Nilai & Kategori & $\begin{array}{c}\text { Keterangan } \\
\text { Tindakan }\end{array}$ \\
\hline A & Kesesuaian RPP dengan pelaksanaan & & & \\
\hline \multirow[t]{3}{*}{1} & Pembelajaran & & & \\
\hline & a. Pengecekan kesiapan kelas & 5 & $\begin{array}{l}\text { Amat } \\
\text { Tinggi }\end{array}$ & Amat Berhasil \\
\hline & b. Apersepsi & 5 & $\begin{array}{l}\text { Amat } \\
\text { Tinggi }\end{array}$ & Amat Berhasil \\
\hline \multirow[t]{4}{*}{2} & Kegiatan Inti & & & \\
\hline & a. Penguasaan materi & 4 & Tinggi & Berhasil \\
\hline & b. Strategi pembelajaran & 4 & Tinggi & Berhasil \\
\hline & c. Penggunaan bahasa & 5 & $\begin{array}{l}\text { Amat } \\
\text { Tinggi }\end{array}$ & Amat Berhasil \\
\hline \multirow[t]{5}{*}{3} & Penutup & & & \\
\hline & a. Refleksi/rangkuman & 5 & $\begin{array}{l}\text { Amat } \\
\text { Tinggi }\end{array}$ & Berhasil \\
\hline & b. Tindak lanjut & 4 & Tinggi & Berhasil \\
\hline & Jumlah & 32 & & \\
\hline & Rata-rata & $=32 / 7=4.57$ & $\begin{array}{l}\text { Amat } \\
\text { Tinggi }\end{array}$ & Amat Berhasil \\
\hline $\mathrm{B}$ & Pemberian Motivasi kepada Siswa & 4 & Tinggi & Berhasil \\
\hline \multirow[t]{4}{*}{$\mathrm{C}$} & Pengelolaan Kelas & 4 & Tinggi & Berhasil \\
\hline & Jumlah & 8 & & \\
\hline & Rata-rata & $\begin{array}{c}=8 / 2= \\
4\end{array}$ & Tinggi & Berhasil \\
\hline & Rata-rata total & $\begin{array}{c}=4.57+4=8.5 \\
7 / 2=4.29\end{array}$ & Tinggi & Berhasil \\
\hline
\end{tabular}

Keterangan: Hasil Observasi Kolaborator yang diolah.

Berdasar tabel di atas selanjutnya dapat dianalisis bahwa kualitas guru dalam pembelajaran siklus 2 memiliki nilai rata-rata total $=4.29$ kategori tinggi, jika dikonsultasikan dengan indikator kinerja kualitas guru dalam pembelajaran minimal = 3.5, maka nilai tersebut lebih tinggi 0.54

Berdasar pembahasan seluruh siklus di atas, dapat diinterpretasikan berikut: (1) Hasil pembelajaran yang dicapai siswa pada studi awal baik proses maupun hasilnya belum mampu mencapai tujuan pembelajaran, baik berkaitan dengan kualitas proses siswa dalam pembelajaran maupun prestasi belajar yang dicapai siswa. (2) Hasil pembelajaran yang dicapai siswa pada siklus 1 baik proses maupun hasil walaupun hasilnya lebih baik dibandingkan dengan yang diperoleh pada studi awal, namun secara keseluruhan belum mampu mencapai tujuan pembelajaran dan belum mampu mencapai indikator kinerja/ indikator keberhasilan, hal ini berarti penerapan exploration learning model belum berhasil sehingga memerlukan perbaikan, baik perencanaan (RPP) maupun pelaksanaannya pada siklus 2. (3) Hasil pembelajaran yang dicapai siswa pada siklus 2 baik proses maupun hasil telah berhasil dengan baik, dan 
hasilnya jauh lebih baik dibandingkan dengan yang telah dicapai pada studi awal maupun siklus 1, hal ini berarti exploration learning model telah berhasil mencapai tujuan pembelajaran atau indikator kinerja/indikator keberhasilan sehingga pada siklus 2 ini tindakan dihentikan.

Berdasar hasil interpretasi di atas, selanjutnya dapat didiskusikan sebagai berikut: (1) Jika pembelajaran IPA menerapkan model exploration learning model, maka nilai rata-rata kelas dengan memahami materi Kemagnetan yang dicapai siswa akan meningkat. (2) Jika pembelajaran IPA menerapkan model exploration learning model, maka persentase ketuntasan hasil belajar dengan memahami materi Kemagnetan yang dicapai siswa akan meningkat. (3) Jika pembelajaran IPA menerapkan exploration learning model, maka kualitas proses siswa dalam pembelajaran dengan memahami materi pelajaran Kemagnetan akan meningkat. (4) Jika pembelajaran IPA menerapkan exploration learning model, maka kualitas guru dalam pembelajaran dengan memahami materi Kemagnetan akan meningkat.

\section{Pembahasan}

Pembelajaran IPA pada materi Kemagnetan di kelas 9 dengan menerapkan exploration learning model bisa meningkatkan kualitas proses pembelajaran di dalam kelas baik oleh siswa (minat, motivasi, kemandirian, kerja sama kelompok, tanya jawab dengan guru) dan kualitas guru dalam pembelajaran (kegiatan di dalam RPP) semakin baik, pengumpulan tugas secara individu persentase juga naik.

Kelebihan dari exploration learning model membuat anak didik lebih percaya atas kebenaran atau kesimpulan berdasarkan percobaannya sendiri, mengembangkan sikap untuk mengadakan studi explorasi tentang ilmu dan teknologi, akan terbina manusia yang dapat membawa terobosan-terobosan baru dengan penemuan sebagai hasil percobaan yang diharapkan dapat bermanfaat orang lain. (Rusman, 2012:47)

Demikian juga dengan guru dalam menyampaikan pembelajaran, untuk Menyusun strategi pembelajaran, metode pembelajaran, Teknik evaluasi yang sesuai dengan karakteristik kelas dan materi yang disajikan. Materi akan mudah dikuasai apabila siswa terlibat secara emosional dalam kegiatan belajar. (Abdorrakhman Gintings, 2008:6).

Di sini peran guru sangat besar untuk mengembangkan potensi anak didik, karena guru berperan dalam membantu perkembangan peserta anak didik untuk mewujudkan tujuan hidupnya secara optimal. Keyakinan ini muncul karena manusia adalah makhluk yang lemah yang dalam perkembangannya senantiasa membutuhkan orang lain dalam berkembang untuk menjadi pribadi yang lebih baik (E Mulyasa, 2013:35). Penelitian Tindakan kelas merupakan suatu cara bagi guru untuk menemukan apa yang terbaik di dalam situasi kelas mereka sendiri sehingga keputusan tentang proses pembelajaran dapat diambil sebaik-baiknya (Mohammad Asrori, 2007:3).

Penelitian ini dengan menerapkan exploration learning model memperbaiki proses pembelajaran IPA yang pada dasarnya sering menggunakan metode eksperimen yang identik dengan tugas baik itu dalam bentuk soal-soal atau tugas laporan praktikum atau tugas proyek. Pengalaman yang dialami oleh siswa secara langsung dapat tertanam dalam ingatannya. Keterlibatan secara fisik dan mental serta emosional, siswa 
diharapkan dapat diperkenalkan pada suatu cara atau kondisi pembelajaran yang dapat menumbuhkan rasa percaya diri dan juga perilaku yang inovatif dan kreatif. (Rusman, 2012:47). Metode Eksperimen saja tidak cukup untuk mengukur keberhasilan proses pembelajaran IPA sehingga diperlukan metode pembelajaran yang lain untuk bisa meningkatkan pembelajaran IPA yaitu exploration learning model. Metode ini bisa dijadikan rujukan bagi guru IPA dalam kegiatan belajar mengajar di kelas.

Penelitian Tindakan Kelas yang peneliti lakukan dengan menerapkan empat langkah, yaitu: Perencanaan, Tindakan, Pengamatan dan Refleksi untuk siklus 1 dan siklus 2 (Asrori, 2007:74). Teknik Analisa data yang peneliti gunakan adalah Teknik deskriptif dengan mean (rata-rata hitung), persentase (\%), dan kategori-kategori dan kalimat-kalimat. (Nazir, 2009:448). Penelitian Tindakan Kelas merupakan penelitian berjenis penelitian kualitatif, maka data-data yang berupa angka atau data statistik yang selanjutnya dikualifikasikan menjadi bentuk kategori-kategori dan kalimat-kalimat yang telah disesuaikan dengan tujuan penelitian.

Penelitian sebelumnya dalam pembelajaran IPA menerapkan Model Team Accelerated Instruction yang merupakan strategi pembelajaran yang memadukan pembelajaran kooperatif yaitu siswa belajar menggunakan Lembar Kerja untuk mengukur tingkat kemampuan siswa dalam bekerja sama dengan kelompok saat melakukan praktikum, dan pembelajaran individual karena setiap siswa memasuki kelas dengan pengetahuan, kemampuan dan motivasi yang berbeda-beda. Saat guru mempresentasikan materi pembelajaran ada sebagian siswa yang tidak memiliki pengetahuan prasyarat untuk mempelajari materi pelajaran, akhirnya gagal mencapai tujuan pembelajaran dan tidak bisa mengukur proses pembelajaran.

Dapat diambil kesimpulan untuk pembelajaran IPA pada materi Kemagnetan ini peneliti menggunakan exploration learning model karena bisa untuk mengukur keberhasilan proses belajar mengajar bagi guru, serta keaktifan siswa dalam pengumpulan tugas baik itu dalam bentul soal-soal atau portofolio.

\section{KESIMPULAN DAN SARAN}

Hasil Penelitian dengan judul penelitian Peningkatan kualitas proses dan hasil pembelajaran materi kemagnetan melalui exploration learning model pada siswa kelas IX-D semester genap SMPN 1 JEMBER Tahun Pelajaran 2019-2020, memperoleh kesimpulan sebagai berikut: (1) Penerapan pembelajaran exploration learning model dalam pembelajaran IPA dapat meningkatkan nilai aktivitas belajar siswa dalam pembelajaran untuk memahami materi Kemagnetan, dengan bukti empiris sebagai berikut: nilai kualitas belajar siswa dalam pembelajaran pada studi awal $=2,14$ nilai (rendah), pada siklus 1 meningkat menjadi $=2,71$ nilai (cukup), dan pada siklus 2 meningkat lagi menjadi 4,00 nilai (tinggi). (2) Penerapan exploration learning model dalam pembelajaran IPA dapat meningkatkan nilai rata-rata tugas individu siswa dalam memahami materi Kemagnetan, dengan bukti empiris sebagai berikut: nilai rata-rata tugas individu yang dicapai siswa pada studi awal $=65,82$ (cukup), pada siklus 1 meningkat menjadi $=72,88$ (cukup), dan pada siklus 2 meningkat lagi menjadi $=85,42$ (tinggi). (3) Penerapan exploration learning model dalam pembelajaran IPA dapat meningkatkan nilai persentase ketuntasan hasil belajar dalam memahami materi Kemagnetan, dengan bukti empiris sebagai berikut: nilai persentase ketuntasan hasil 
belajar pada studi awal $=39,39 \%$ (amat rendah), pada siklus 1 meningkat menjadi $=$ $45,83 \%$ (rendah), dan pada siklus 2 meningkat lagi menjadi $=100 \%$ (amat tinggi). (4) Penerapan exploration learning model untuk memahami materi pelajaran kemagnetan dapat meningkatkan nilai kualitas guru dalam pembelajaran IPA, dengan bukti empiris sebagai berikut: nilai kualitas guru dalam pembelajaran pada studi awal belum dinilai, nilai kualitas guru dalam pembelajaran pada siklus $1=3.36$ (tinggi) nilai dan pada siklus 2 meningkat menjadi 4.29 nilai (amat tinggi). (5) Disarankan agar nilai rata-rata tugas individu, nilai ketuntasan tugas individu, kualitas proses siswa dalam pembelajaran dan kualitas guru dalam pembelajaran memahami materi Kemagnetan meningkat, hendaknya guru IPA dalam pembelajaran menerapkan exploration learning model dengan maksimal.

\section{DAFTAR PUSTAKA}

Asrori, Mohammad. 2007. Penelitian Tindakan Kelas, Bandung: Wacana Prima.

Gintings, Abdorrakhman. 2008. Esensi Praktis Belajar dan Pembelajaran, Bandung:

Humaniora.

Nazir, Mohammad 2009. Metode Penelitian, Bogor: Ghalia Indonesia.

Mulyasa, E. 2013. Menjadi Guru Profesional Menciptakan Pembelajaran Kreatif dan Menyenangkan, Bandung: Remaja Rosdakarya.

Prasodjo, Budi, dkk. 2008. Teori dan Aplikasi Fisika untuk SMP kelas 9, Bogor:

Yudhistira.

Rusman. 2012. Strategi Belajar Mengajar, Jakarta: Rineka Cipta.

Sugiyono. 2012. Metode Penelitian Kuantitatif, Kualitatif, $R \& D$, Bandung: Alfabeta. 